\title{
IMPLICATIONS OF THE CENTRAL BANK'S CONTROL ON DEPOSITS AND CREDIT IN ISLAMIC BANKS
}

SOSYAL BILIMLER

DERGISI

\author{
MERKEZ BANKASI'NIN MEVDUAT KONTROLÜNÜN \\ ETKÍLERI VE İSLAMİ BANKALARDA KREDI
}

ANKARA UNIVERSITY

JOURNAL

OF

SOCIAL SCIENCES

\section{Hendreen Findi YOUSIF}

Bingöl Üniversitesi, Sosyal Bilimler Enstitüsü, İş İdaresi Bölümü, Yüksek Lisans Öğrencisi, hndrinf@gmail.com

10.33537/sobild.2019.10.2.14

\section{Makale Bilgisi}

Gönderildiği tarih: Kabul edildiği tarih: Yayinlanma tarihi:

17-05-2019 24-06-2019 30.06.2019

\section{Article Info}

Date submitted: Date accepted:

Date published:

17-05-2019

24-06-2019

30.06.2019

\section{Anahtar sözcükler}

Merkez Bankast, Ekonomik Rol, Kontrol, Íslami Bankalar, Hedefleri, Endişeler, Mali, Bilgi, Gelişme, Düzenleyici ve Etkileri.

\section{Keywords}

The Central Bank, Economic Role, Control, Islamic Banks, Objectives, Concerns, Financial, Information, Development, Regulatory And Effects.
$\ddot{O z z}$

Merkez bankası, para politikasının yöneticisidir. Bu nedenle bankactlik sisteminde kontrolör rolündedir.

Merkez bankasi, İslami bankalan da geleneksel bankalan kontrol ederken kullandiğı araçlarla kontrol edecektir; çünkü merkez bankası, İslami bankalar ile geleneksel bankalar arasında ayrim yapmamiştır. Dolayısıyla, bu sürecin kontrol ve iktisadi amaçlar üzerinde etkileri olacaktir.

Şayet merkez bankalar, İslami bankalarn operasyonlarinı anlarsa, İslami bankalarin kontrolü için uygun enstrümanlar kullanabilecektir. Böylece, reel milli geliri arttırmak suretiyle, para ve ürün arzı üzerinde kontrol sağlamak gibi tüm amaçlarina ulaşacaktır.

\section{Abstract}

The central bank is the manager of monetary policy. Thus it is plays the role of controller in the banking system.

Central bank will control Islamic banks by the same instruments which it used in the control on the Traditional banks, because the central bank didn't distinguish between Islamic banks and Traditional banks. So, this process will have effects on the control and economic aims.

If central banks understand the Islamic bank operations they will be able to use suitable instruments for the control on Islamic banks. So, they will reach to all aims, like control on money and product supply, increasing the real national income. 


\section{Introduction}

The emergence and development of banking institutions has led to these institutions playing an important role in the supply of cash and thus in inflation, prompting governments to intervene in the work of these institutions to control the money supply and, consequently, to affect the state of the economy. The state does this through the Central Bank, which uses a number of tools in this process, and the nature of the banking business, which depends primarily on the investment of the depositors and the importance of these banks in the economy, the funds of depositors through the Central Bank, which uses a number of tools in this process also. Central banks have become banks' observers through the powers granted by law.

Islamic banking has developed under the rule of the capitalist system, which is governed by the central banks. It was therefore necessary for Islamic banks to abide by the laws in force regarding the supervision of the central bank without paying attention to the specificity of the Islamic banks. Problems between central banks and Islamic banks these problems include the Central Bank's supervision of credit and deposits in Islamic banks, which is reflected in the economy and banking supervision.

\subsection{The Importance of Study}

The effectiveness of the Islamic banks and their economic role is mainly based on the collection and collection of savings (bank deposits) and on the investment of these funds in an optimal manner Since the process of banking supervision on Islamic banks include the control of the Central Bank on deposits and credit in Islamic banks and affect Which is reflected on the economy and banking supervision This study was to be able to know these effects and implications, the importance of study lies in the importance of the role that can be played by Islamic banks in economic development at the level of the state, Which helps it to play its developmental role in the national economy.

\subsection{The Aim of Study}

The study aims to analyze and evaluate the economic and regulatory effects of the Central Bank's control over deposits and credit in Islamic banks by identifying the central bank's concept of deposits of Islamic banks and financing and investment instruments in terms of practicality and the implications of this concept.

\subsection{The Problem of Study}

The problem of study is to know the economic and regulatory effects of the Central Bank's supervision on credit and deposits in Islamic banks in practice by focusing on the Jordanian banking system. By answering the following questions:

1. How can central banks control Islamic banks in the absence of an Islamic central bank at the local and international levels? What tools do you use in this control? Do these instruments take into consideration the nature of the Islamic banking business? Do these instruments take into consideration the mechanisms and methods of investment that are used by Islamic banks?

2. What is the effect of the Central Bank's supervision on the actions of Islamic banks? Does this oversight lead to its objectives in all cases? And why?

3. Does this control affect the economy, especially on real national output and on monetary expansion?

\subsection{The Hypotheses of Study}

1. Some of the control tools used by the Central Bank on Islamic banks are commensurate with the nature of its outstanding work, which requires specialized supervision;

2. Evaluation of the methods of control used by the Central Bank and its impact on Islamic banks and mechanisms of development.

\subsection{The Plan of Study}

The first objective is the concept, objectives and tools of the Central Bank's care on credit and deposits in Islamic banks. The second topic concerns the regulatory effects of the Central Bank's concept of deposits and investment. The third topic concerns the economic impact of the Central Bank of Deposits and investment on Islamic banks.

\section{Central Bank's Control on Credit and Deposits in Islamic Banks}

\subsection{Control of Deposit}

\subsubsection{The Concept and Objectives of Control of Bank Deposits}

The Jordanian Banking Law No. 28 of 2000 defines the deposit as "a sum of money given by a person by any means of payment to another person who is obliged to refund it upon request or in accordance with agreed terms. The depositor acquires ownership of the deposited money and has the right to dispose of it with its obligation to refund the same to the applicant and be refunded with the same type of currency deposited.

The concept of bank deposit control stems from the concept of legal deposit and the objectives of this control. The definition of deposit control objectives is linked to the nature of the banking business and the legal framework 
under which all banks operate. Banking supervision can be defined as "a set of methods and tools used by the Central Bank within the legal framework in place to ensure the safety of public deposits with banks and return them to their owners upon request or in accordance with the deposit contract".

It is noted from the previous definition that the main objective of the Central Bank's supervision of bank deposits is to ensure the return of these deposits to their owners, In addition to other basic objectives, including:

- Ensure that banks do not mismanage these deposits;

- Ensure that banks do not infringe on deposits;

- Ensuring the exploitation of deposits;

- Ensuring that banks fulfill their obligations towards deposit holders;

- Ensuring economic stability, as banks' breach of their commitments leads to an economic deterioration that does not bear fruit;

- Control of money supply.

\subsubsection{Banking Deposit Control Tools}

In our definition of bank deposit control, we said that there are methods and tools used by central banks under the applicable laws to implement the control. On the basis of this article and the like in the law, the Central Bank implements its control policy on banks.

Article (36) of the Jordanian Banking Law No. (28) for the year 2000 states that "The Bank shall maintain sufficient liquidity to meet its business requirements and take into account the diversity of its assets in order to reduce its risks and to exercise its business in accordance with the proper management and accounting methods This law and the regulations and orders issued thereunder"(Jordanian Banking Law No. (28) for the year 2000).

The methods and tools used by the Central Bank for Banking Supervision can be divided into.

\subsubsection{First- Quantitative Methods}

1. Reserve Ratio Policy: Central banks usually issue instructions to operating banks forcing them to keep a percentage of their deposits. This proportion is proportional to the state of the country's economy of inflation or recession.

2. Legal Liquidity Ratio: Under Article (36), the Central Bank requires banks to keep liquid assets in accordance with the banking rules attributed to the total deposits. The Central Bank usually issues instructions to calculate this ratio. This ratio is also considered a tool of credit control as is known.

3. Ratio of Capital to Deposits: Instructions are issued by the Central Bank to all banks that the bank's capital should not be reduced by a certain percentage of deposits. This means that the bank must stop accepting deposits or increasing its capital when deposits reach a certain level.

Second- Qualitative Methods: Here we refer to the methods used to ensure the safety of deposit procedures in practice. And those methods that contribute to increasing the efficiency of quantitative methods related to deposit control and these methods:

1. Determine the types of liquid money that should be held by commercial banks

(Nassar, 1996:32).

\section{Determine the funds that enter the liquidity ratio.}

3. Field banking inspection: It is intended to ascertain the validity of the operations that are conducted on the accounts of customers. The description of the procedures in which the opening of accounts and disposition and other matters relating to the accounts open in the bank.

\subsection{Control of Credit}

The control of central banks on deposits and credit in the financial sector is one of the most important roles of controlling the supply of money and preserving the rights of depositors and stability of the national currency. It seeks to achieve financial and economic stability of the public system through regulating and rationalizing supervision of the work of financial institutions.

The financial institutions are an integral part of the banking system, which requires that these institutions be subject to the rules and regulations of the international financial institutions. Regulatory and supervisory suit the specificity of the nature of their work and their needs and to ensure their work in equal conditions in the market competitive and to coordinate performance and strengthen undertaken by both Shari'a and central banks bodies to carry out its mandated economic development role in all fields in accordance with the rules and principles that guarantee the safety of their financial positions and to ensure the rights of clients

\subsubsection{The Concept and Objectives of Credit Control}

The Jordanian Banking Law referred to credit as "payment of money from the bank to the customer in exchange for the right to recover it with its interest and any other dues and any guarantee, guarantee or undertaking issued by the bank" (Jordanian Banking Law No. (28) for the year 2000). 
The process of controlling the credit granted by banks to their customers is a very important process because of the risks it poses to the bank itself, depositors and, consequently, the economy in general. Therefore, the central banks have a clear and deliberate policy of controlling credit. The control of credit means that the Central Bank uses certain methods and tools to control the investments and banking facilities carried out by the banks and direct them under the applicable laws to achieve certain objectives. This requires the creation of effective information systems so that the central bank can do the job well, "The central objective of the central bank's policy is to impose strict and effective control over credit and monetary policy, "In the absence of accurate and comprehensive information on the factors affecting banking reserves"(Siegel, 1987: 63).

The central bank controls credit to achieve certain objectives, the most important of which is regulating the activity of the banking system and directing it to the right and appropriate destination (Sami Khalil, 1982:544,545,585). And draw the monetary policy of the state to achieve the public good. Credit control has become more important after the abolition of the gold rule, where it has become an important target to run economic cycles and achieve a high level of economic activity and employment, and stability of international exchanges, and promote economic growth (Al-Shammari, 1999:112).

\subsubsection{Credit Control Tools}

In order for the central bank to achieve the mentioned objectives, it uses quantitative tools and methods to enable it to reach its objectives. The researcher will mention these tools briefly and in a manner that serves the objectives of this study.

First- Quantitative Methods: These methods are usually aimed at influencing the overall volume of credit in banks, regardless of the type of credit or the purpose of the credit granted. Among these methods:

1. Redemption Price: It is a traditional style of the central bank as the bank of banks and its latest lender. In short, raising the discount rate negatively affects the amount of credit granted (Ramadan, 1996:35).

2. Open Market Operations: It is the central bank selling bonds in the market or buying bonds from the market according to the target it intends to achieve. The sale of bonds in the market leads, in theory, to a drop in bank deposits indirectly, as well as reduced funds available for financing, and vice versa for the bond purchase by the central bank (Khalil, 1982: 625).

3. Determining the Ratio of Credit to Deposits: It means forcing banks not to exceed credit granted a certain percentage of deposits. In other words, banks should increase their deposits if they want to increase their banking facilities.

4. Change the Reserve Ratio: We refer to Article 36 of the Jordanian Banking Law on this subject, where the Central Bank can issue instructions to banks to increase or reduce the reserve ratio commensurate with its objectives, and it is known that this increase limits the ability of banks to expand the granting of credit.

Second- Qualitative Methods: This is one of the modern methods that have become central banks to follow, and aims to guide credit to the desired aspects and purposes that serve the economy and contribute to its growth:

1. Defining the Margin Required for Margin Financing Operations: Which is the establishment of the central bank to determine the margin required in these banking operations commensurate with the target of the Central Bank, increasing the margin leads to a decline in credit granted to finance the purchase of securities and other operations (Ramadan, 1996:148).

2. Change the Interest Rate on some Types of Loans: The central bank has been raising interest rates on consumer loans, such as loans to people for tourism, for example, and lowering the interest rate on productive loans to channel credit to productive loans.

3. Literary Persuasion: It is an attempt to influence the behavior of credit banks through articles in newspapers and magazines and direct dialogue to match this behavior with the objectives of the Central Bank (objectives of monetary policy and development goals). 4 - Determine the share of credit: The Central Bank shall set ceilings for loans and advances in general and not exceed or limit certain ceilings to be used to finance certain sectors and not to exceed these ceilings (Khalil, 1982:623).

4. Statement on Banking Risks: The Central Bank compels banks to declare the amount and quality of credit granted to their clients, whose facilities are increased by a certain amount, (Khalil, 1982:624) as well as the statement of guarantees received by the banks in return for granting such facilities. All this is done by mobilizing all the banks - including the Islamic ones - into a unified model. The Central Bank aims to ensure that commercial banks apply the legal provisions related to facilities and guarantees and find a good information system that serves all banks in making credit decisions. The disclosure of bank risks helps banks provide credit information to current or potential customers to help them make better and more accurate credit decisions (AlKhayat, 2004:232). 
Section Two: The Regulatory Effects of the Central Bank's Concept of Deposits and Investments of Islamic Banks in the Traditional Way

Banking control tops the functions of the central bank or monetary authority in most countries of the world, but the extrapolation of the history of central banks reveals the extent to which its inception is largely linked to the idea of controlling cash and credit, which is the core of banking supervision.

The consideration of the objectives of supervision of banks clearly shows that these objectives are in the principle of reconciling conflicting interests.

\subsection{The Concept of the Central Bank of Deposits of Islamic Banks}

The concept of legal deposit has been identified in the first section. In order to determine the dimensions of this definition, it is necessary to discuss the concept of the Central Bank accurately for the deposit:

1. The Central Bank takes into account the legal concept of the deposit, which refers explicitly to the transfer of ownership of money from the depositor to the bank, that is, the contract between the depositor and the bank is a loan contract, The loan is returned to its owner upon request or at the specified time when the contract is concluded. The borrower has the right to work with the money of the loan.

2. This concept of deposit makes it the duty of regulators, including the central bank to work to maintain the funds of depositors (lenders) because it is responsible for the banks working and it is given by the legal force to obtain this money in this form, and therefore it maintains the funds of depositors through The tools that we mentioned in the first section, whether these tools directly such as cash reserve ratio or indirect capital adequacy, it aims to reduce the desire of the bank to dispose of these deposits in a risk to increase profits. Depositors in traditional banks within the concept of deposit referred to will not benefit from increasing investment or increasing the return on the investment of funds deposited in the bank, but will receive a predetermined interest rate regardless of the results of the bank. 3. The problem in the Central Bank's concept of deposit is true only for conventional bank deposits, while this concept is mistaken for deposits in Islamic banks with respect to investment accounts deposited in the Islamic Bank under the Mudaraba contract. The Fuqaha 'on his health. In which the ownership of the owner of the money (the depositor) continues for his money and the ownership of the bank is not transferred, although the owner of the money authorizes the bank to act in the money within the condition of holding the Mudaraba between them.
In this concept of investment accounts, the owners of the funds who have been speculating with the Islamic Bank are willing to bear all the risks resulting from the investment of their funds except the bank's infringement or shortfall. This raises an important question to the Central Bank: Is the Central Bank the right to prevent owners of funds from disposing with their money? Is he entitled to protect them from the risk of investing their money, which they voluntarily accepted in order to obtain profits?

\subsection{The Regulatory Effects of the Central Bank's Concept of Deposits in Islamic Banks}

We mentioned in first section of this study that the most important goal of deposit control is to ensure that banks can return these deposits to their owners upon request or on time specified in the contract. The first requirement of this section was to clarify the concept of the Central Bank for deposit in the Islamic Bank The Central Bank of the characteristics of investment deposits in Islamic banks whose main advantage has been shown is that it is not a loan on the bank as is the case in conventional banks.

The regulatory objectives of the Central Bank must be affected by its concept of deposits, which will certainly affect its control over deposits in Islamic banks and the objectives of such controls. To study the regulatory effects resulting from the Central Bank's concept of deposits in Islamic banks, the researcher will mention the monitoring tool on deposits in short and analyze the regulatory effect resulting from the application of this tool within the concept of the Central Bank of deposits in the Islamic Bank. In view of the difference in the concept of investment deposit between the Islamic Bank and the Central Bank:

First- Cash Reserve Ratio: It means keeping a certain percentage of each deposit with the central bank as the first line of defense if the bank has liquidity problems.

This objective is achieved for commercial bank deposits for the reasons indicated when the legal definition of the deposit is mentioned. As for the deposits of Islamic banks, this objective is partially realized for some deposits (accounts) in Islamic banks (Al-Sarhi, 2001:18)

The implementation of the Central Bank of the control of investment accounts in Islamic banks using this percentage negatively because it will deduct amounts from investment accounts to protect their owners who

Invest in this type of accounts willing and understanding of the risks of this matter. It is not in their interest to disrupt their money to protect them or they would have kept the money in their pockets. Some researchers here suggest that this ratio should be applied to the credit accounts of Islamic banks and to the non- 
investment part of investment accounts (Al-Khayat, 2004:85) to achieve the regulatory objective of applying this ratio to Islamic banks. In the absence of such proposals, the researcher suggests that the agreement between the Islamic Bank and the Central Bank to finance government purchases in a Murabaha way to buy from these funds and low Murabaha ratios (Al-Sarhi, 2001:29).

Some suggested that all reserves should be invested by the central bank in Islamic investment portfolios or deposited in investment accounts in international Islamic banks and split profits between the Islamic Bank and the Central Bank (Rayhan, 2002:15).

Second-General Liquidity Ratio: The application of this percentage to Islamic banks may achieve the objective which is partly hoped, but this could lead to the disruption of part of the money deposited in Islamic banks on speculation (for investment) because the Islamic Bank has to maintain the required liquidity ratio even though most of its deposits Investment. The objective of this ratio is to ensure that the Bank is able to meet its obligations at sudden withdrawals. I also say that the central bank does not take into consideration the nature of investment deposits, especially restricted investment deposits, (Sweilem, 2005:203) which are added to the ratio even though they are usually invested for a relatively long period. In general, the use of cash reserve ratio and general liquidity ratio can be said that the different nature of the investment accounts in the Islamic banks than the investment accounts in the conventional banks, which is the deposit of the first to insure the depositors themselves, the second is a commitment to the traditional bank, Liquidity to meet this obligation as opposed to Islamic banks (Al-Sarhi, 2001:22).

The problems of applying the liquidity ratio to Islamic banks should be overcome by depositing amounts in investment accounts opened by the Central Bank with the Islamic Bank, which will also lead to Islamic banks obtaining the latest lender services from the Central Bank without violating the provisions of Islamic law (Abu Ghuda, 2001:9).

Third-Ratio of Capital to Deposits: We mentioned in the first section that the application of this ratio to banks may have some, especially banks with limited capital, to stop accepting deposits if the acceptance of more deposits will exceed the proportion set by the Central Bank. This is logical for the legal concept of deposit, which applies to all conventional

The introduction of investment deposits (Islamic accounts) in Islamic banks within this percentage will lead to harming the Islamic banks and owners of these accounts both because of the nature of these deposits and the nature of the work of Islamic banks, which was discussed earlier. The researcher considers that this ratio is adjusted in relation to the Islamic banks so that the investment part of the investment accounts is excluded from this ratio and included the credit accounts and the non-investment part of the investment accounts which are usually invested in the bank's guarantee as is the case with the credit accounts. Which makes the control effect of these tools more effective and accurate and takes into account the nature of investment accounts in Islamic banks?

As for the regulatory effects resulting from the use by the Central Bank of the qualitative methods in supervising bank deposits, field bank inspections lead to the same regulatory objectives regardless of the type and nature of deposits, whether in conventional banks or Islamic banks. But some other methods have been mentioned such as determining the types of money.

Which should be kept by the commercial banks and determine the funds that enter into the liquidity ratio have been talked about and analyzed when looking at the effects of control resulting from the use of cash reserve ratio and liquidity ratio to serve the objectives of this study.

\subsection{The Concept of the Central Bank of Credit in Islamic Banks}

We referred to the concept of the Central Bank of Credit. The central bank adopts the legal concept of credit. By analyzing the concept of the Central Bank for bank credit, the following can be observed:

First- The Central Bank considers all the facilities granted to customers with banks as credit, which makes the relationship always between the bank and the client with the relationship of lender to borrower. This makes the borrower committed to the bank to pay certain amounts at specific times and that non-payment of these amounts by the borrower means the bank's loss. Here, it can be said that the central bank's view of the Islamic banking operations, which usually result in the flow of money from the Islamic Bank to its customers, is the same as the view of the flow of money from the traditional bank to its customers. This is certainly a view leading to many fallacies; the requirements of Islamic banks contradict the objectives of these banks and at the same time do not achieve the objectives of the Central Bank of Control.

Second- Different methods of financing in Islamic banks than in conventional banks: - The concept of credit in Islamic banks differs from the concept of central banks; it means trust and includes deliberation, retention, authorization to act to contract or to invest money (Abu Ghuda, 2001:9).

We have noticed that the definition of bank credit law is the result of traditional banking practice for a very long time. This definition was taken from the point of view 
of conventional banking only and did not take into account the concept of credit in Islamic banks, although there is a fundamental difference between the two methods of financing. The researcher finds that the difference between the two methods in short to serve the purposes of this study because of the existence of a large number of writings on this subject. The most important differences can be summarized as follows:

1. Many of the financing methods of the Islamic Bank depend on the method of participation with the client in the various investments. Thus, the money obtained by the client from the Islamic Bank in the financing of speculation or participation, or the farmer does not become a debt in the hands of the client. But depends on the outcome of the work. If the profit is distributed in the agreed proportions either losses are distributed by the contribution of each party in the capital and the client (financier) is responsible for the return of money to the bank in case of loss only if proven to be breached or shortened. Thus, the money in such types of financing cannot be considered a debt in the hands of the client, which means deviating from the supervision of the Central Bank for its stated objectives. We will then explain the implications of this particular view of some of the financing methods in Islamic banks;

2. As for the other types of financing in Islamic banks, they involve credit in the end, although different funding. This means that all the Islamic Bank's futures sales, such as the sale of Murabaha to buy and sell the peace, end with the emergence of debt in the hands of the client, which enables the application of the control tools on credit used by the Central Bank on Islamic banks in this case.

\subsection{The Regulatory Effects of the Central Bank's Concept of Credit in Islamic Banks}

The Central Bank controls deposits and credit to preserve the rights of depositors and maintain the stability of the national currency.

Due to the fact that Islamic banks are subject to this control, this affects them in some ways positively and negatively in other areas because of the nature of these banks' deposits, their specificity and the methods of financing them.

The effect of the Central Bank's control on deposits and credit in Islamic banks is the application of the laws imposed on it as a private bank among the private banks. In light of this, the Central Bank can use a qualitative control method for Islamic banks and exploit the cash reserves deposited with the Central Bank through agreements between the two banks to exploit these funds.

First- The Control Effects of Quantitative Methods within the Concept of the Central Bank of Credit in Islamic Banks: The re-discount rate by the central bank may be influential and yield the desired control over traditional banks. As for the Islamic banks, it does not produce any control effects on this instrument, because it is not possible for the Islamic Bank to resort to re-discounting the commercial papers with the Central Bank because it is not possible to deduct the commercial papers originally for the customers of the bank. The fact that the Central Bank of the open market operations affect the banks and individuals who do not take the provisions of the legitimacy of the transactions in mind, because these operations focus on the purchase or sale of securities represent a debt interest most of the time, which is away from the Muslim investor and the Islamic Bank when they abide by the provisions of Sharia Islamic.

The researcher believes that the existence of an Islamic financial market could make this tool has a better regulatory impact on Islamic banks. But the experience of issuance of securities under the provisions of Islamic law is still in its beginning in Jordan, making use of the Central Bank of this tool is not effective in the control of the Central Bank on credit in Islamic banks.

By changing the reserve ratio, the central bank can affect the banks' ability to grant credit as discussed earlier in this study. However, the supervisory effect resulting from the application of this tool to Islamic banks regardless of the nature of investment deposits or the nature of financing methods to participate in them can be negative especially since the central bank's objective of applying this tool to banks is to protect depositors 'funds and limit banks' And monetary expansion. It is known that the methods of financing participation in Islamic banks do not lead to the violation of these objectives, which the central bank seeks to achieve, but may be the opposite is true, which means that the Islamic Bank's commitment to this percentage may not achieve the objectives of the Central Bank, but mostly in the method of Investment Bank Islamic is not dependent on participation, but on the sale of Murabaha to buy or other instruments that give rise to debt in the hands of dealers.

Second- The Control Effects of the Qualitative Methods Within the Concept of the Central Bank of Credit in Islamic Banks: If we look at the qualitative methods currently applied by the Central Bank to control credit in Islamic banks, we find that the lack of observance of the Central Bank of the nature of some investment tools in Islamic banks sometimes lead to counterproductive or do not lead to any result at other times. For example, change the interest rate on some types of loans or change the margin ratio. The impact on financing Islamic banks for some sectors is not supposed to be as effective as conventional banks. The researcher believes that the qualitative methods can be very influential in the control of credit in Islamic banks through the use of the method of literary persuasion and encourage Islamic banks to increase the share of financing methods based on participation and speculation of the total investment to 
improve the quality of credit and its impact on the national economy General.

Third- The Regulatory Effects Resulting from the Use of Disclosure of Banking Risks within the Concept of the Central Bank of Credit: The nature of the disclosure of banking risks was discussed in the previous section. It is worth mentioning that the research carried out in the field of supervision of Islamic banks did not give this tool the attention it deserves, despite its importance and the importance of its consequences.

In order to clarify the regulatory and credit effects arising from the use of the bank risk disclosure, it is necessary to clarify what this disclosure is in detail and how to apply it in practice.

All banks prepare a bank risk statement in a form that usually takes the following form: develop the disclosure of banking risks to suit the work of all banks, whether traditional or Islamic (Mohammed, 1995:58). The researcher believes that the need to add fields of speculation and participation to detect the dangers of banking to increase its effectiveness, and the purpose of the desired.

Section Three: The Economic Effects of the Central Bank's Supervision on Deposits and Credit in Islamic Banks

The collection and analysis of banking risk data provides the central bank with a wealth of necessary information on the most important and most important activity of the banks, lending, investment and finance, which directly affects the activities of different economic sectors. The analysis also allows the Central Bank to

Table 1.

\begin{tabular}{|r|r|r|r|r|r|r|}
\hline Password & $\begin{array}{r}\text { Short } \\
\text { Statement }\end{array}$ & $\begin{array}{r}\text { In } \\
\text { Kind }\end{array}$ & Character & $\begin{array}{r}\text { Real } \\
\text { Estates }\end{array}$ & $\begin{array}{r}\text { Letters } \\
\text { of Credit }\end{array}$ & Guarantees \\
\hline & Granted & & & & & \\
\hline
\end{tabular}

Source: Mahmoud Sartawi, 2001, Central Banks' Relationship with Islamic Banks, Conference on the role of Islamic Banking Institutions in Investment and Development, Sharjah, UAE, 5-7 May 2001.

And fill this form with the required information The Central Bank can know the ceilings granted to each trader and the amounts used by the classified by the guarantees and then the central bank collects the information for each trader received from all banks and then re-sent to banks that deal with this person to be able to these banks To stand on the total indebtedness of this client, which helps to protect banks and increase their ability to make more accurate credit decisions.

But this model - despite its benefits - is counterproductive - at times - because it does not take into account the nature of Islamic banking. It can be said that this tool is required for the Islamic banks in some financial instruments such as Murabaha for buying or documentary credits, but they are counterproductive when declaring the banking risks related to the financing of participation or speculation, because the Islamic Bank to declare these ceilings within the same Form for banking notification.

It can be said that weak Islamic banking awareness and failure to take into account the specificity of Islamic financing in the traditional banking environment leads to misinterpretation of the information contained in this disclosure, especially in the case of syndicated or speculative financing operations. Therefore, the Banking Risk Department at the Central Bank is required to know the collateral behind the credit facilities Investment and finance) provided by each commercial bank, and thus determine the trust of the depositor, regarding its deposit in banks.

\subsection{Impact on Monetary Expansion}

It aims to control the volume of credit provided by banks to various economic sectors, and influence the quantity increase or decrease through the use of the Central Bank of its quantitative and qualitative tools.

\subsubsection{The role of Banks in Monetary Expansion}

The phenomenon of inflation is one of the most important phenomena of modern economy that governments try to control through monetary policy, which is usually managed by the Central Bank. Inflation is defined as an increase in the overall supply of cash over the total supply of goods and products over a given period of time, leading to an increase in the overall price level. Or "any increase in cash circulation resulting in an increase in effective financial demand for the total supply of goods and products in a given period of time, leading to an increase in the overall level of prices", cash supply is sometimes expressed in monetary expansion (Nassar, 1996:60). 
The money supply consists of three types of money: Legal and bank money (current and demand deposits) in addition to quasi money (futures and savings deposits, shares, bonds and other liquid assets) (Shafei, 1968:147).

If we look at the nature of credit activity of commercial banks, we find that the credit operations of these banks are limited to lending and borrowing. "The credit operations of conventional banks are limited to lending and borrowing because, under the laws of banks, they are a type of transaction that creates commercial debt from selling or leasing," (Abu Ghuda, 2001:9).

The nature of the credit operations in conventional banks leads to monetary expansion (increased money supply) because they directly contribute to the process of multiplying criticism, which in turn increases the banking awareness, which peaked at the end of the last century and the beginning of this century. This has been the cause and remains of interest in the central bank's supervision of banks as the bank and the director of monetary policy, which is the control of the supply of cash the most important part. The tools used by the Central Bank to achieve this goal have already been clarified. The most important are the ratio of cash reserves, general liquidity ratio, credit to deposit ratio, open market operations, re-discount rate, "Most developing countries are controlling monetary and credit expansion as two main objectives of their monetary policy, in the face of inflation, which has become one of the most important contemporary economic phenomena"(Al-Ayadi, 2002:301).

\subsubsection{The Role of Islamic Banks in Monetary Expansion}

Monthly and annual central bank reports often indicate and show money supply. The central banks consider the process of controlling the money supply from indicators of economic progress.

The nature of credit in Islamic banks is different from credit in traditional banks because of the different approach that governs Islamic banks. However, Islamic banks may contribute to monetary expansion by contributing to the doubling of cash through some of the financing tools used in Islamic banks, such as forward sales of all kinds and good loans. He says

The role of Islamic banks in monetary expansion is relatively less than the role of conventional banks in a single banking market because transactions in Islamic banks lead to a balance between the supply of money and the supply of commodities. The closer we get to the real application of the image of Islamic contracts and transactions, the more the Islamic banks have lost their ability, or the less they derive from deposits and monetary expansion (Sartawi, 2001:31).
The combination of more liquid assets by Islamic banks from several investors does not in itself create a real banking system and does not make Islamic financial instruments a means of exchange, as is the case with traditional Islamic banks, for example Murabaha, Murabaha are not debt instruments that can be used in financial markets, as is the case with traditional financial instruments. In contrast, Islamic financial instruments are tools geared towards production (Al-Radadi, 2002:16).

Islamic finance tools, especially those that adopt a participatory or leasing approach, lead to increased commodity production in a way that is commensurate with the increase in money supply. Islamic banks, in the Islamic view of money, consider that they should perform their primary function as a tool for exchange. Cannot be traded or sold, but can be used to stimulate economic activity through the union with other factors of production and thus to find real investments.

The ability of Islamic banks to collect and mobilize the largest amount of resources in terms of size are not the only positive role in economic development, but they also have a greater capacity to mobilize and create adequate resources for financing development by pooling long-term resources that are desperately needed development and creating resources of a risk nature lacking in developing countries despite its practical importance in development (Abu Zeid, 1996:28).

We can say from the above that the effect of Islamic banks in increasing the cash circulation (monetary expansion) is a limited effect (theoretically) for the following reasons:

1. Islamic banks accumulate excess liquidity in the public into long-term investment accounts normally, which leads to the indirect withdrawal of cash from the market, because spending on consumer needs is declining with the low liquidity in the hands of the people. Especially with those not allowed withdrawing their money only by the agreed time when opening the account;

2. Most of this liquidity is used in real investments (i.e. investments in tangible assets), which means increased production, thus creating a balance between money supply and commodity supply;

3. The cash available at the Islamic banks shall be used in investment instruments based on the principle of actual participation in the profits or losses resulting from the investment of such funds. Cash loans are not provided to customers of Islamic banks except in very narrow cases and for social and religious cases considered under good loans. 
But some of the financing tools in Islamic banks, such as the sale of Murabaha for buying sometimes contributing to monetary expansion by opening current accounts and increasing the use of checks as a result of purchases and sales.

In the fact that Islamic banks have been operating over the past decades, it can be seen that these banks have contributed to monetary expansion - in practice but less than conventional banks.

And that this is an exit by Islamic banks from the objectives of its establishment for the following reasons:

1. Islamic banks allow the owners of investment accounts to withdraw at any time in return for waiving profits. The terms of opening accounts and practical application in the Jordanian Islamic banks allows the owners of investment accounts to withdraw in case they waive the profits of withdrawals;

2. Not exceed the period of investment accounts for a year in most cases;

3. Lack of investments for available funds in investment in investment instruments that depend on the actual participation in the results of investment, such as speculation and participation;

4. The rate of Murabaha financing is very high compared to other financing tools;

5. The use of Murabaha financing is the cornerstone of Islamic banks' investments. It is known that this investment tool contributes to monetary expansion more than other instruments such as speculation and participation;

6. Not to exploit the available funds for investment optimization and the following table an example of one year shows the amount of available funds and the amount of money actually invested;

7. There is a huge amount of money being disrupted from the funds deposited with Islamic banks, no matter what the justifications, such as the absence of a lender or the mandatory reserve ratio, which confirms that Islamic banks do not meet the ambitions;

8. All this leads to the Islamic banks' contribution to monetary expansion more than expected. While Islamic banks should play a relatively opposite role to the role they currently play in practice to contribute to economic development;

9. The Central Bank's supervision of Islamic banks as part of its control over banks in order to control the monetary expansion is bearing fruit despite the reservations we have made previously. This is because Islamic banks are contributing in a practical way to increasing monetary expansion;
10. The central banks in cooperation with Islamic banks to form committees to find the best ways to control Islamic banks to achieve the central bank's goal to control the money supply and at the same time reduce the negative effects of the quantitative methods followed by the Central Bank in the control of banks Islamic. This can be achieved through the creation of a specific regulatory mechanism to put pressure on Islamic banks to increase the volume of their investments in investment and financing instruments which depend on the principle of participation because of their positive effects in reducing monetary expansion.

\subsection{Impact on Monetary Expansion}

General National Product (GNP) is defined as the sum of the monetary values of all final goods and services produced by the economy over a specified period of time (usually one year) (Al-Shammari, 1999:273).

Others define it as the monetary value of all types of products and services produced and traded in the market by a particular country over a given period of time, usually one year (Al-Shammari, 1999:273).

There are several ways of calculating the national product, including the value added method and other methods based on the differentiation between the final production and intermediate production.

The national income is the sum of the returns received by the owners of factors of production and these revenues include the return of labor wages and salaries and bonuses and royalties of property profits and benefits and profit. Only income derived from participation in the production process is included in the calculation of national income (Al-Shammari, 1999:274).

National income is measured in a number of ways, including the acquired method or the method of national expenditure or value added (Kassem, 1981:65).

The study of national output and national income and follow-up is one of the tools of measuring the economic activity of the state and one of the tools to judge the progress or economic delay to them during a certain period of time. The increase in GNP and national income is an indicator of the high standard of living and economic well-being of citizens.

Real General Domestic Product (RGDP) and real national income are more accurate indicators of economic progress because of their calculation after considering the change in the value of money to cancel the effect of inflation.

It can be said that banks are considered the most important financial institutions that can contribute to increasing national income and real national output if they can provide the necessary funding for various and different investments in a way that contributes to 
increasing national income and national output in a balanced manner while maintaining the greatest possible stability (Stability of the value of money), which requires a balanced balance between the increase in money supply and commodity supply. It is therefore the real direct investment that ultimately leads to the real impact on national product and national income and thus is the one that influences economic development.

The regulatory objectives of the Central Bank should be to drive economic growth by directing bank credit to direct real investment. And thus contribute to the actual increase in real national income and real national income.

But under an interest-based capital based economy, it is very difficult to achieve such an equation because the increase in the volume of loans - even the productive loans as they call them- leads in one way or another to an increase in money supply more than the increase in commodity supply, And thus to the adverse effect on the real national product and the real national income. The quality control of the central bank on banks operating in the country, which direct banks to productive loans, will lead to an increase in national product and nominal national income. The national product and the real national income may not reach the desired increase or even decline if the rate of increase in the supply of money more than the rate of increase in the supply of goods significantly.

In the case of supervision of Islamic banks, some of the quantitative methods used by the Central Bank to control them sometimes limit the ability of Islamic banks to increase the credit granted in the fields of participation in real investments as we have seen previously, which negatively affects the national product and national income.

It is well known that financing methods in Islamic banks, especially those based on participation; usually work to strike a balance between growth in money supply and commodity supply. Which means a more stable value of money and thus a real increase in national product and national income; Therefore, the researcher believes that the central bank's consideration of the nature of Islamic investment bank deposits, the nature of financial and investment tools in Islamic banks, and the application of qualitative supervision to push Islamic banks to increase their real investments based on participation and speculation in particular will lead to the desired objectives of the Central Bank's control over Islamic Banks.

The main difference between Islamic and conventional finance is the treatment of risk, and how risk is shared.
In this step we examine what these differences can teach us about risk and risk management in conventional banking and financial markets.

The two main forms of Islamic finance are bank finance and issuing Islamic securities (called sukuk).

In conventional terminology you might think of these as debt - bank loans and bond issues respectively, but that is inaccurate. Those categories cannot be applied to pure Islamic finance.

In Islamic finance interest is prohibited. If an enterprise is financed by debt with an obligation to pay interest, the risk of the business is not being shared fairly.

Instead, Islamic finance requires that finance is provided on the principle of profit and loss sharing. Under shariah law finance can be provided through several types of contract. Each type specifies how risk is shared between the enterprise and the supplier of finance.

One such contract is a mudarabah. This specifies in advance how profits and losses are to be shared between the financier and the entrepreneur. Profits are shared in a predetermined ratio, so the financier's return fluctuates according to business profitability. Losses, except those caused by the entrepreneur's fraud or negligence, are to be borne entirely by the financier. Contrast that with a conventional loan where the financier has a contractual right to receive interest (and capital repayment) irrespective of the condition of the borrowers' business.

Does Islamic finance actually operate with pure profit and loss sharing?

Islamic banks and sukuk are currently based on contracts that formallymatch what is required by shariah law.

But many scholars argue that the way they operate is not based on Islamic profit and loss sharing. A buyer of a sukuk, for example, expects to receive an assured yield comparable to an interest-bearing bond. Owners of bank deposits expect capital certainty comparable to deposits in a conventional bank. Islamic banks smooth fluctuations in profits to provide this capital certainty. And they channel most of their lending through shariah compliant methods that, unlike mudarabah, do not involve participating in enterprise risk. 
Therefore a number of scholars observe that most Islamic finance is not different in substance from conventional finance.

\section{How do Islamic banks manage risk?}

A pure Islamic bank would share risks - profits and losses - with its customers. The ethical code underlying shariah does not seek to abolish risk: it recognises that business enterprise is desirable but is inherently risky. Therefore banks need to manage risks to keep them below undesirable levels.

Islamic banks also need to ensure their risk management does not involve purely speculative risk taking, which is prohibited under shariah. As you will see next week, conventional investment banks can appear to be betting on exchange rate changes or on the prices of financial assets.

So, what methods are available to manage risk?

Islamic banks can use some of the methods available to conventional banks. To minimize risk of default they can investigate and monitor the businesses they finance. In fact, profit and loss sharing might create an additional reason for monitoring the enterprise.

However, Islamic banks face particular challenges in risk management. Some instruments that conventional banks use are not available. This includes conventional financial derivatives. You will learn later that a financial derivative is an instrument whose value is determined by another financial instrument. This directly contravenes the principle of materiality: materiality means finance must be tied to real economic activity. Shariahcompliant derivative markets have not developed.

As you can see, Islamic finance is based on ethical principles including sharing risk; profit and loss sharing; and on real activity. What do you feel conventional banks can learn from these principles?

\section{Conclusions}

The researcher, through what was presented and analyzed, reached the following results:

1. The Central Bank shall control deposits and credit in Islamic banks and shall use the same tools and methods used in the control of conventional banks;

2. The Central Bank does not take into account the specificity of Islamic investment bank deposits, but considers it a debt in the Islamic Bank. As for the financing and investment methods in Islamic banks, from the point of view of the Central Bank, it is a debt of the Islamic Bank regardless of the names;
3. The Central Bank's view of the work of Islamic banks negatively affects the regulatory objectives of the Central Bank and the economy in general;

4. The Central Bank's control over deposits and credit in Islamic banks sometimes achieves the objectives of the Central Bank of Control because of the ineffectiveness of financial instruments based on participation in Islamic banks;

5. Central banks do not exercise effective quality control on Islamic banks, as is the case in the control of traditional banks;

6. Central banks use the same models and documents to control the traditional banks and Islamic banks, leading to a reverse understanding of the objectives of the preparation of these models and documents, especially disclosure of banking risks;

7. The reality of Islamic banks proves that the ambition is not achieved by increasing the means of financing based on participation. The central bank is doing nothing about it.

\section{Recommendations}

To overcome the shortcomings in achieving the regulatory and economic objectives of the Central Bank's supervision of deposits and credit in Islamic banks, the researcher recommends the following recommendations:

1. Because Islamic banks have social objectives in addition to profit, they must direct their investments to direct investment to contribute effectively to development of all kinds.

2. Because Islamic banks use different investment formats and instruments that differ from the method of financing with interest, such as Musharaka, Mudaraba, Murabaha. These instruments differ in terms of the degree of risk and in terms of achieving the objectives of the society. Therefore, the Central Bank should use a qualitative supervisory method for Islamic banks;

3. The Central Bank shall encourage Islamic banks to finance long-term projects. The Islamic Bank shall allocate part of the profits to establish industrial and commercial companies in a manner that does not harm the liquidity that should remain with the Islamic Bank;

4. Utilization of cash reserves deposited with the Central Bank through the conclusion of agreements between the Central Bank and Islamic banks to exploit these funds in financing government purchases with low Murabaha rates or participation with the government;

5. Central banks should work with their governments to develop and develop financial markets in which Islamic financial instruments, especially Mudaraba bonds, are traded, thus helping central banks 
to use open market operations to achieve their objectives in relation to the supervision of Islamic banks;

6. Developing quantitative and qualitative methods to control the work of Islamic banks to achieve the objectives of banking supervision. Such as the development of qualitative methods to push Islamic banks to increase the share of financing methods based on participation and speculation of their total investments. Which is reflected positively on the economy in general, especially on increasing income and real national output;

7. Developing the models and documents used in the supervision by the Central Bank to expand and include the work of Islamic banks in line with the objectives of preparing these forms and documents, such as adding fields related to the financing of speculation and participation to the disclosure of banking risks currently used in Jordan;

8. The Central Bank shall prepare inspectors for the supervision of Islamic banks provided that they are aware of the legal, legal and banking matters and are responsible for banking operations in Islamic banks;

9. Establishment of a special department in the Central Bank to follow up the work of Islamic banks, and control over them.

\section{References}

Moneim -Abdul M. A. Z. (1996). The Economic Role of Islamic Banks between Theory and Practice, International Institute of Islamic Thought, Herndon, Virginia, USA.

Ghuda -Abu A. S. (2001). Credit, Conference on the Role of Islamic Banking Institutions in Investment and Development. Sharjah, 5-7 May.

Ayadi-Al A. S. (2002). Monetary and Financial Policy in Islam and its Role in Inflation. International Institute of Islamic Thought, Herndon, Virginia, USA.

Ghareeb-Al N. (1996). Islamic Banking Supervision. International Institute of Islamic Thought, Herndon, Virginia, USA.

Ghareeb -Al, N. (1996). The Origins of Islamic Banking. House of Apollo, Cairo, Egypt.

Hiti- Al, A. R. (1998). Islamic Banks between Theory and Practice. Dar Osama, Amman, Jordan.

Khayat-Al, A. and Al-Ayadi, A. (2004). Jurisprudence of Transactions and Investment Formations. Dar AlMutaqadimah Publishing and Distribution, Amman, Jordan.
Masri-Al, R. Y. (1993). The Origins of the Islamic Economy. Dar Al-Qalam, Damascus, Surba.

Radadi -Al, M. B.M. (2002). Management of Islamic Banks after Globalization of Capital Markets. Arab Organization for Administrative Development, Cairo, Egypt.

Radadi -Al, L. (2001). Development of the Relationship of Islamic Banks with the Central Bank of Yemen. Conference on the Role of Islamic Banking Institutions in Investment and Development, held in Sharjah, 7-9 May.

Shammari -Al, N. N. (1999). Money, Banking, Theory and Practice, Dar Zahran. Amman, Jordan.

Al-Shammari, N. N. and Al-Sharouf, M. M. (1999). Introduction to Economics, Dar Zahran, Amman, Jordan.

Al-Wadi, M. and Abdul-Karim, A. (2006). Islamic Economics. Al-Quds Open University Publications, Amman, Jordan.

Cook, M.J. (1987). Central Banking. Translated by: Abdul Wahid Al Makhzoumi, Dar Al-Tali'ah, and Beirut, Lebanon.

Kassem, I.M. (1981). Analytical Economics. Cairo University, Cairo, Egypt.

Khalil, S. (1982). Money and Banking. Dar Kadhma, Kuwait.

S. H., Mohammed (1995). Journal of Financial and Banking Studies, III(3), 3.

Ramadan, Z. and Mahfouz, J. (1995). Banking Department. First Edition, Dar Safe Publishing \& Distribution, Amman, Jordan.

Rayhan, B. (2002). Central Control and Islamic Banking Course. Jordan Islamic Bank.

Risk Management in the Global Economy, SOAS University of London (web)

Sartawi, M. (2001). Central Banks' Relationship with Islamic Banks. Conference on the role of Islamic Banking Institutions in Investment and Development, Sharjah, UAE, 5-7 May 2001.

Shabra, M.O. (1996). Islam and the Economic Challenge, translated by: Mohamed Samhouri. International Institute of Islamic Thought.

Shafei, M. Z. (1968). Introduction to Money and Banking. Dar Al-Nahda, Cairo, Egypt.

Siegel, B. (1987). Money, Banking and Economics. translated by Taha Abdullah et al., Dar Al-Marikh, Riyadh, Saudi Arabia. 
Sweilem, M. (2005). Management of Traditional Banks and Islamic Banks: A Comparative Approach. Cairo, Egypt. 